\title{
A Decade of XBRL Research in Accounting in Indonesia: A Literature Study
}

\author{
ARFAH HABIB SARAGIH* \\ ANDINI SORAYA \\ ADANG HENDRA WAN \\ Universitas Indonesia
}

\begin{abstract}
XBRL research in Indonesia has only begun to show its existence after a decade of the presence of this technology, which is around 2010. This phenomenon in Indonesia has motivated the researchers to look at the history of the development of $X B R L$ research as a sub-area of Accounting in Indonesia in bibliographic form for over one decade. The researchers are making an effort to describe the development of XBRL research in Indonesia and review the possible potential for XBRL research in Indonesia in the future. The method used is a literature review on published articles indexed in Scopus and Sinta. Based on the 21 articles selected, XBRL research topics in Indonesia are divided into four areas, i.e., its influence on business, adoption, technology development, and XBRL education. Based on the review results, XBRL research in Indonesia is still limited in using empirical research with quantitative methods. This study could be a relevant illustration of how adopting the XBRL format is implemented in developing countries like Indonesia. This comprehensive literature review could enrich the knowledge and inspire other developing countries, which may be at the same stage as Indonesia, to adopt this technology in the business environment.
\end{abstract}

Keywords: eXtensible Business Reporting Language, XBRL, Indonesia, literature review

Abstrak-Penelitian XBRL di Indonesia baru mulai terlihat eksistensinya pasca satu dekade hadirnya teknologi tersebut, yaitu sekitar pada tahun 2010. Fenomena yang ada di Indonesia tersebut memotivasi peneliti untuk melihat sejarah perkembangan penelitian XBRL sebagai suatu sub area akuntansi di Indonesia dalam bentuk bibliografi selama periode satu dekade. Peneliti berusaha menggambarkan perkembangan riset XBRL di Indonesia dan meninjau kemungkinan potensi riset XBRL di Indonesia di masa mendatang. Metode yang digunakan adalah review literatur atas published articles terindeks Scopus dan Sinta. Berdasarkan 21 artikel yang terpilih, topik penelitian XBRL di Indonesia terbagi menjadi empat area yaitu pengaruhnya pada bisnis, pengadopsian, pengembangan teknologi, dan pendidikan XBRL. Berdasarkan hasil tinjauan, penelitian XBRL di Indonesia masih terbatas dalam menggunakan penelitian empiris dengan metode kuantitatif. Studi ini dapat menjadi ilustrasi yang relevan tentang bagaimana adopsi format XBRL diterapkan di negara

*Corresponding author: arfah.habib11@ui.ac.id

The author thanked the Department of Fiscal Administration, Faculty of Administrative Sciences Universitas Indonesia, for supporting and funding this research through FIA UI Grant 2021. 
berkembang seperti Indonesia. Tinjauan pustaka yang komprehensif ini dapat memperkaya pengetahuan dan menginspirasi negara-negara berkembang lainnya yang mungkin berada pada tahap yang sama dengan Indonesia dalam mengadopsi teknologi ini di lingkungan bisnis.

Kata Kunci: eXtensible Business Reporting Language, XBRL, Indonesia, literature review

\section{Introduction}

Along with the emergence of the 4.0 industrial revolution era, internet use in corporate business is increasing, especially as the main channel of communication to stakeholders (Janvrin and No, 2012). Recently, governments, professional organizations, and financial reporting standards setters globally set out to look at the utilization of eXtensible Business Reporting Language (XBRL) and interactive data as one way of achieving transparency and overseeing corporate reporting (Roohani et al., 2009). As a result, XBRL, globally and especially in most developed countries, has gained tremendous popularity since its publication in early 2000 . The benefits of using XBRL allow the company to electronically report its financial statements with guaranteed interoperability (Bonsón et al., 2009), accuracy (Troshani et al., 2015), and flexibility (Torre et al., 2018). Furthermore, by developing XML format, XBRL-based financial statements can be easily read by machine, or in this context is the internet.

XBRL research has been widely conducted and has contributed to practice for both companies and government agencies. It is not only limited to accounting purposes such as financial statements but it can also be utilized for auditing and data management in the public sector. Several previous studies have attempted to conduct a comprehensive review and provide feedback on future research opportunities related to XBRL (see, e.g., Alles and Debreceny, 2012; Baldwin et al., 2006; Doolin and Troshani, 2004; Hoitash et al., 2020; Janvrin and No, 2012; Mindzak, 2009; Perdana et al., 2015; Srivastava and Liu, 2012). Some literature, however, only explains the studies without digging deeper into the classification of themes and methods in XBRL research. In contrast, some others made their classifications into several themes and/or methods. For example, Mindzak (2009) consolidated it into three (3) main focuses, i.e., descriptive 
studies on XBRL, XBRL assurance, and other research areas related to XBRL. Janvrin and No (2012) classified it into four (4) primary themes, i.e., management support and involvement, implementation approach (outsourcing versus insourcing), organizational readiness or expertise, and control over the XBRL reporting process.

Other researchers also classified XBRL research into three to four more focused main themes, such as Srivastava and Liu (2012) - assurance, effects, implementation; Doolin and Troshani (2004) - XBRL as a technology, XBRL as a standard, XBRL as a business tool, XBRL as education; and Hoitash et al. (2020) - investor use of XBRL, auditing and assurance, academic use of XBRL, inline XBRL, and XBRL in international scope. However, unlike others, Perdana et al. (2015) classified XBRL research into four main themes whose divisions are quite complete and cover all subtopics by having a clear basis in their division, i.e., XBRL's impact on business, XBRL's adoption, XBRL's technical development, and XBRL's education.

In Indonesia, XBRL research has only begun to show its existence after a decade of its presence, which is around 2010. However, research related to this topic has not had a significant trend in Indonesia compared to other countries. In fact, regulators such as the Bank of Indonesia (BI) as well as the Financial Services Authority (FSA), and Indonesia Stock Exchange (ISE) have imposed the use of XBRL format for firms' financial reporting (see, e.g., Wijanarko and Moedjiono, 2015; Mayapada et al., 2020). This paper aims to present a literature review of research related to XBRL implementation in Indonesia. To achieve the research objectives, the following research questions (RQ) will be answered: RQ1. What research has been done in the field of XBRL in the context of Indonesia over the last decade (2011-2021)? RQ2. What methods have been used in XBRL research for the last decade (2011-2021)? And RQ3. What are the recommendations for the potential future research agenda regarding XBRL research in Indonesia?

We are motivated to perform this literature review for several reasons. First, the presence of XBRL in Indonesia has been around a decade, and the development of research published at reputable outlets tends to be limited. This study seeks to describe what has been researched about XBRL over the past decade and provide some future 
research directions. Second, to the best of our knowledge, the literature review of XBRL research in Indonesia has not been carried out for the last decade. This motivates the author to provide a more recent summary of the XBRL research in Indonesia. The impact resulting from the utilization of XBRL should be an exciting topic for further discussion about its existence. Finally, the phenomenon in Indonesia motivates us to observe the historical development of XBRL research as an accounting sub-area in Indonesia, in the form of a bibliography over a decade.

The selection of literature to the classification scheme of this study is similar to and follows guidelines from previous researchers, especially research conducted by Perdana et al. (2015). By conducting a literature review on conceptual and empirical articles, this study specifically focuses on XBRL in the context of Indonesia. The current study attempts to provide an overview of the development of XBRL research in Indonesia and examine the future potential of XBRL research in Indonesia. This study contributes to the increasing literature of XBRL, specifically in Indonesia. In addition, this study is important to increase users' knowledge and/or potential users about the impact of using this technology on businesses. This study's results can illustrate how the progression of XBRL technology is implemented, especially in developing countries such as Indonesia. This study might also enhance knowledge on XBRL and even an inspiration for other countries, which may be at the same stage as Indonesia in adopting this technology in the business environment. As we all might know, academic research is essential to help regulators, information providers and consumers, software developers, and the XBRL community adapt the technology to gain international adoption (Alles and Debreceny, 2012).

The rest of this paper focuses on the following sections in the order Perdana et al. (2015) performed. Section 2 explains the overview of XBRL and the development of XBRL in Indonesia; Section 3 describes the article extraction and classification methods; Section 4 provides a summary of XBRL research; Section 5 is a review of research that has been conducted; Section 6 illustrates the suggested XBRL research framework and potential future studies, and Section 7 presents conclusions and limitations. 


\section{XBRL}

\subsection{XBRL Overview}

The digitization of financial information reports was eventually developed through XBRL (eXtensible Business Reporting Language) format. XBRL comes with a special role in business financial reporting and identifies each data and relationship between them. In a sense, XBRL is a flexible open-source knowledge representation language based on the eXtensible Markup Language (XML) of the World Wide Web Consortium (Debreceny and Farewell, 2010). XBRL aids obvious Internet reporting for performance as well as financial data of an organization. XBRL's financial reporting standards system is flexible because it corresponds to each company and does not go out of the general concept of accounting in the Generally Accepted Accounting Principle (GAAP). XBRL provides tags for each item to be read automatically by the computer and combined according to user specifications both inside and outside the company (Arnold et al., 2012).

Based on XBRL.org, more than 50 countries have used XBRL to distribute entity information to related stakeholders. This is supported by a study by Pinsker and Wheeler (2009), where the implementation of XBRL is more effective and efficient in decision making because it improves the ability to obtain information that is considered beneficial to non-professional investors. In addition, Baldwin et al. (2006) stated that XBRL serves potential enhancements and challenges to information quality via a wellestablished standard taxonomy and therefore achieves the qualitative characteristics of financial reporting.

Furthermore, in the research results, Perdana et al. (2015) mentioned that this function owned by XBRL turned out to have a huge impact on accounting. The shift in the reporting paradigm from paper-based to XBRL-based reporting has created faster, better, and cheaper business processes. XBRL also facilitates the creation of a leaner financial reporting chain. Various external and internal parties involved in the financial reporting chain benefit the most from XBRL. Other than that, XBRL also cuts down information processing costs and enhances capital market information transparency, 
which improves investors' expectations about the potential future crash risks (Zhang et al., 2019).

\subsection{Development of XBRL in Indonesia}

The implementation of XBRL utilization in Indonesia has generally been mandated by several government agencies such as the Bank of Indonesia (BI) as well as and the Financial Services Authority (FSA) and Indonesia Stock Exchange (ISE) (see, e.g., Wijanarko and Moedjiono, 2015; Mayapada et al., 2020). The existence of XBRL in Indonesia was first carried out by the Bank of Indonesia (BI). After 2010, BI began assessing XBRL as an Integrated Reporting System in monetary and financial system stability reports. The first phase conducted by $\mathrm{BI}$ is the sharia banking reporting system as a pilot project in 2014. Along with developing the capital market industry and the need for fast, efficient, and uniform report information that can reinforce facilities creation in the adoption of business intelligence, XBRL also becomes an integrated solution in the standardization of information reporting language for ISE.

Based on information on the ISE website, since 2012, it has begun the development of XBRL-based reporting by preparing a taxonomy that represents a specific reporting for the company's financial statements to be socialized to all listed companies. The taxonomy development was completed by ISE in 2014 and came into effect by requiring the company to submit financial statements in XBRL format in 2015 publicly. Year after year, the rate of submission of financial statements in XBRL format continues to increase. In addition, ISE always provides socialization and assistance for registered companies to improve compliance with financial reporting obligations in XBRL format.

The mandatory use of the XBRL format in financial reporting for listed firms can be explained by institutional theory (see, e.g., Troshani et al., 2015; Wang et al., 2014). The institutional theory serves as a framework in explaining the compulsory XBRL adoption where regulatory assures the successful adoption of mandatory XBRL. After regulators' mandate to apply XBRL to the financial reporting of listed firms, as explained and predicted by the institutional theory, firms shall adapt to comply with 
this mandate. In other words, the power and pressure of the regulation make sure the success of XBRL application to financial reporting.

\section{Journal Extraction and Classification Methods}

This paper specializes in the literature review of XBRL research in Indonesia by mapping the latest XBRL research in 2011-2021. The criteria set for this literature review are limited to studies that have been published in reputable international journals and proceedings (indexed in Scopus Q1-4) and national journals (indexed by Sinta S16) from 2011 to May 2021. Based on the criteria, however, the initial papers obtained tend to be limited. Thus, we decided to add one more criterion by adding students' theses from the top ten universities in Indonesia.

This study consists of three stages in extracting and classifying articles. First, the researchers explored all available articles on various platforms, with the characteristics of articles related to XBRL in Indonesia. The search process was carried out from July 2020 to May 2021. Based on the criteria determined, we documented the two earliest XBRL studies in an academic article in 2014 (see Wirabuana and Nugraha, 2014) and 2015 (see Wijanarko and Moedjiono, 2015). This is in line with the beginning of the XBRL development in Indonesia, wherein the 2010 Bank of Indonesia began to study and assess the utilization of the XBRL format. Meanwhile, the first semester of 2021 became the last year of the article, according to the time of this study. Therefore, the selection range of articles is from 2011 to the first semester of 2021.

A scheme is required to form research synthesis (e.g., Perdana et al., 2015). Thus, in the next stage, we examined the articles to find the main similarities and differences between the contents of the articles, thus creating a classification scheme for this study. Guided by previous studies (see, e.g., Alles and Debreceny, 2012; Baldwin et al., 2006; Doolin and Troshani, 2004; Hoitash et al., 2020; Janvrin and No, 2012; Mindzak, 2009; Perdana et al., 2015; Srivastava and Liu, 2012), this study will classify each article based on research data collection methods and research themes. Thus, this study classified the collected articles based on their methodological research approach (see 
Table 3). In the third phase, we categorized XBRL research by research theme (see Table 4). Figure 1 below illustrates the extraction and classification process of articles. Figure 1.

Phases of Extraction and Classification of Articles

\begin{tabular}{|c|c|c|}
\hline $\begin{array}{c}\text { First Stage } \\
\text { The Exploration and } \\
\text { Selection of Articles }\end{array}$ & $\begin{array}{c}\text { Second Stage } \\
\text { Classification of } \\
\text { Articles by Research } \\
\text { Methods }\end{array}$ & $\begin{array}{c}\text { Third stage } \\
\text { Classification of } \\
\text { Articles by Research } \\
\text { Theme }\end{array}$ \\
\hline
\end{tabular}

\subsection{First Stage: Exploration and Selection}

In answering the research questions, this study conducted an integrative review by identifying articles related to XBRL research in Indonesia in the form of scientific articles that have been published online based on the criteria set before. Knowing that there is limited research that discusses XBRL in Indonesia, this study conducted an extensive search using search engine platforms. Search engine platforms such as Google Scholar, Research Gate, Publish or Perish, Directory of Open Access Journal, National Library of the Republic of Indonesia, Garba Rujukan Digital Ristekbrin, and the digital libraries of top ten universities in Indonesia are used to obtain the intended articles. In exploring related literature, researchers use the term "XBRL Indonesia,"; "Extensible Business Reporting Language Indonesia,"; "XBRL Research in Indonesia,"; "XBRL Indonesia Stock Exchange,"; and "digital reporting". Table 1 illustrates the process of selecting articles.

Thus, as reported in Table 1, this study selected as many as 40 papers in the search result before further proceedings. After the evaluation process, 19 articles were excluded from the election because they did not fit the criteria of this study. In addition, two papers were found to be published in two different publishers, and seventeen papers were not indexed in Scopus and Sinta. As a result, 21 articles are processed for literature review. 
Table 1.

Article Selection Scheme

\begin{tabular}{lc}
\hline \multicolumn{1}{c}{ Selection Process } & $\mathrm{n}$ \\
\hline Total search results found using the mentioned keywords & 296 \\
Excluded from evaluation process because it was a non-scientific paper, the same & \\
items, not specifically discussing XBRL in Indonesia context, not thesis from top & \\
ten universities in Indonesia & $(256)$ \\
Articles/thesis processed for evaluation & 40 \\
Excluded from the election because: & \\
Double publication at two different publishers & $(2)$ \\
Not indexed in Scopus Q1-4 & $(13)$ \\
Not indexed in Sinta S1-6 & $(4)$ \\
\hline Articles processed for an integrative review & 21 \\
\hline
\end{tabular}

Table 2.

Types of Publication

\begin{tabular}{ll}
\hline Types of Publication & Definition \\
\hline Scholarly Journal & $\begin{array}{l}\text { Contains empirical research study reports to professionals and } \\
\text { building knowledge. This journal has the highest quality, most } \\
\text { admitted, and most objective with complete details. }\end{array}$ \\
& $\begin{array}{l}\text { Articles written to be accepted or presented at conferences are } \\
\text { usually limited to a specific scope. }\end{array}$ \\
Conference Papers & $\begin{array}{l}\text { A written text that makes evidence of the final assignment that } \\
\text { students have completed their studies in higher education is } \\
\text { written systematically with scientific methods that can be } \\
\text { and Post-Graduate) }\end{array}$ \\
& accounted for.
\end{tabular}

Source: Neuman (2014)

Explanation regarding the classification scheme based on the type of publication can be seen in Table 2. According to Neuman (2014), there are some types of publications, i.e., peer-reviewed scientific journals, internationally published journals, published journals, conference papers, semi-scientific professional publications, news and newspaper magazines, serious opinion magazines, and popular public magazines. However, Neuman considers publications such as news magazines, newspapers, opinion magazines, popular magazines, or radio broadcasts. Internet news summaries are inadequate to be library reviews because many essential details about the research described are not presented. Furthermore, simplified summaries can provide an incomplete or distorted picture of a complete study. Thus, in this study, the selected articles were taken from scientific journals, articles presented in professional meetings, 
and student thesis used as literature to be reviewed. This is because they are included in the category of peer-reviewed scientific journals and publications.

\subsection{Phase Two: Research Methods}

This study classified articles based on research methods used based on our observations, including surveys, secondary data, case studies, design science, interviews, and multi-method approaches (see Table 3).

Table 3.

Classification of Research Methods

\begin{tabular}{ll}
\hline Methods & Definition \\
\hline Case Study & $\begin{array}{l}\text { A study is an in-depth investigation of an enormous amount of } \\
\text { information related to several units or cases for a period or several } \\
\text { periods (Neuman, 2014). } \\
\text { Design Science } \\
\text { problems through innovative artifact creation. Thus, the } \\
\text { researchers build advantageous and fundamental artifacts (e.g., } \\
\text { Hevner et al., 2004). } \\
\text { A study utilizing the existing data of an organization and/or } \\
\text { business, such as financial and accounting reports, archive data, } \\
\text { and publications of statistics data (e.g., Palvia et al., 2007). } \\
\text { A study that utilizes pre-defined and structured questionnaires to } \\
\text { take data from individuals. Questionnaires can be sent by post } \\
\text { (lately, electronic media is used to deliver or operate the } \\
\text { questionnaire) (e.g., Palvia et al., 2007). } \\
\text { A multi-method study involves a single study or more complex } \\
\text { ongoing study program that regularly uses various methods (a } \\
\text { field, survey, experimental, and nonreactive) to achieve the } \\
\text { study's objective. This type of examination is quickly considered } \\
\text { a research style in itself, a different style in the way it is like the } \\
\text { more conventional style it uses (e.g., Bergman, 2007). }\end{array}$ \\
\hline
\end{tabular}

\subsection{Stage Three: Research Topics/Themes}

After observing each selected article by following the XBRL research theme classification guidelines provided by Perdana et al. (2015) using XBRL research samples in the international sphere, the results of XBRL research theme classification in Indonesia generally have the same research theme cluster, i.e., i) The influence of XBRL on Business (see, e.g., Jayani et al., 2020; Junus and Irwanto, 2021;(Mahardika and Harahap, 2018) Mayapada, et al., 2020; Pamungkas and Kristanto, 2019; Prasetyo 
and Apandi, 2019; Saputro and Achjari, 2020; Tohang et al., 2020; Zamroni and Aryani, 2018); ii) Adoption of XBRL (see, e.g., Muchlis et al., 2019); iii) XBRL Engineering Development (see, e.g., Wijanarko and Moedjiono, 2015); and iv) XBRL education such as XBRL teaching and XBRL integration into the accounting curriculum (see, e.g., Wulandari and Ali, 2019; Pujisari and Biyanto, 2019). Table 4 explains the definition and scope of each theme.

Table 4.

XBRL Research Theme Classification Scheme

\begin{tabular}{ll}
\hline Research Theme & Scope \\
\hline XBRL's Impact on Business & $\begin{array}{l}\text { Explaining how XBRL should accompany organizations } \\
\text { and/or businesses to prepare, disseminate, and utilize } \\
\text { financial information effectively and efficiently. }\end{array}$ \\
& $\begin{array}{l}\text { Examining the problems and benefits related to the } \\
\text { implementation of XBRL. }\end{array}$ \\
& $\begin{array}{l}\text { Investigating how XBRL promotes the ability of users of } \\
\text { financial information to use the information to lead them to } \\
\text { more informed decisions. }\end{array}$ \\
XBRL's Adoption & $\begin{array}{l}\text { Investigating XBRL adoption drivers and inhibitors at the } \\
\text { individual and organizational level. It also includes XBRL } \\
\text { adopters' characteristics. }\end{array}$ \\
XBRL's & $\begin{array}{l}\text { Note how XBRL should be developed technically to aid the } \\
\text { integration of organization applications and their business } \\
\text { processes. }\end{array}$ \\
XBRL's Education & $\begin{array}{l}\text { Learning and proposing ways to raise awareness of XBRL } \\
\text { among accountants, lecturers, students, auditors, and users of } \\
\text { financial information. }\end{array}$
\end{tabular}

Source: Perdana et al. (2015)

The theme of research related to the influence of XBRL on business, by Perdana et al. (2015), is a combination of sub-cluster themes that discusses the implementation of XBRL to improve business processes (i.e., the influence of XBRL in accounting and corporate governance, the impact of XBRL in auditing, and the impact of XBRL on decision making and factors of perceptual). In the findings of XBRL research in Indonesia, several similar sub-clusters are included in the first theme. For example, in 
the sub-cluster of the influence of XBRLin accounting and corporate governance, there is information related to earnings management, information asymmetry, financial information environment, and information risk (see, e.g., Mayapada et al., 2020; Pamungkas and Kristanto, 2019; Tohang et al., 2020; Zamroni and Aryani, 2018), on XBRL sub-cluster in auditing (see, e.g., Saputro and Achjari, 2020), and in the XBRL sub-cluster on the factors of decision-making or related to market reaction (see, e.g., Jayani et al., 2020; Junus and Irwanto, 2021).

\section{Descriptive Summary of XBRL Research}

Research on XBRL in Indonesia has intensified from the beginning of 2018 and the highest in 2019. Figure 2 shows the trend of XBRL studies published during the period. The 21 articles consist of 3 international journals, two articles from international proceedings, seven articles from national journals, and nine theses. Further, Table 5 presents the frequency of article types, research methods, and research themes. Finally, an appendix provides more detailed information about the full title, the author(s), and year of publication, as well as research themes and methods.

Figure 2.

Distribution of XBRL Research in Indonesia from Year-to-Year

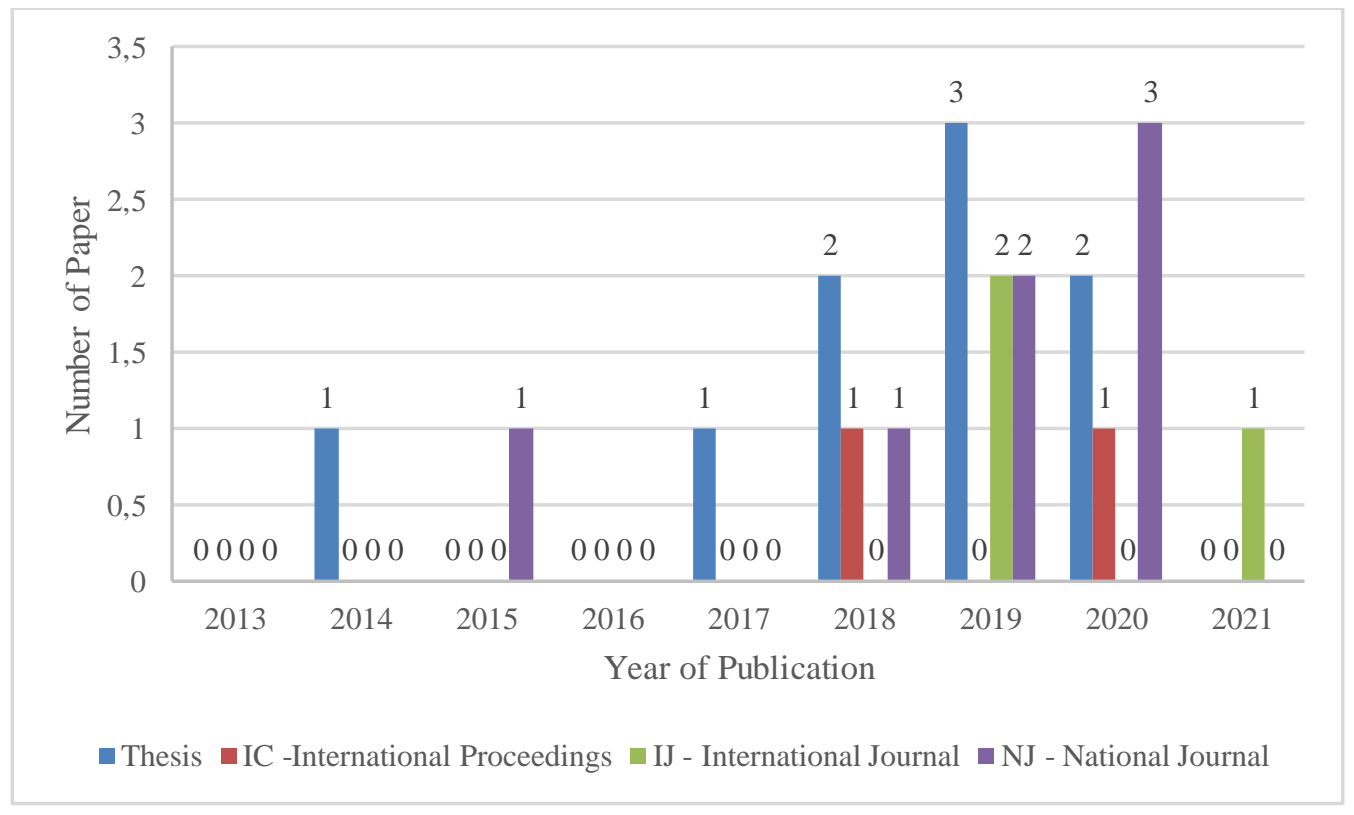


Table 5.

Classification by Article Type, Research Method, and Research Theme

\begin{tabular}{|c|c|c|c|c|c|c|}
\hline \multirow{2}{*}{\multicolumn{2}{|c|}{ Type of Paper and Research Method }} & \multicolumn{5}{|c|}{ Frequency of Research Theme } \\
\hline & & 1 & 2 & 3 & 4 & Total \\
\hline \multicolumn{7}{|c|}{$\begin{array}{l}\text { Scientific journals peer-review (include international } \\
\text { and national journals and proceedings) }\end{array}$} \\
\hline- & Qualitative Study & & & & & 0 \\
\hline- & Secondary Data & 8 & 1 & & & 9 \\
\hline- & Case Study & & & 1 & & 1 \\
\hline- & Survey & & & & 2 & 2 \\
\hline- & Design Science Research & & & & & 0 \\
\hline \multirow{2}{*}{\multicolumn{2}{|c|}{ - Multiple Method }} & & & & & 0 \\
\hline & & 8 & $\mathbf{1}$ & $\mathbf{1}$ & 2 & 12 \\
\hline \multicolumn{7}{|c|}{ Student's Thesis) } \\
\hline & Qualitative Study & & & & & 0 \\
\hline- & Secondary Data & 7 & 1 & & & 8 \\
\hline- & Case Study & & & & & 0 \\
\hline- & Survey & 1 & & & & 1 \\
\hline- & Design Science Research & & & & & 0 \\
\hline \multirow{2}{*}{\multicolumn{2}{|c|}{ - $\quad$ Multiple Method }} & & & & & 0 \\
\hline & & 8 & 1 & $\mathbf{0}$ & $\mathbf{0}$ & 9 \\
\hline Total & & 16 & 2 & $\mathbf{1}$ & 2 & 21 \\
\hline
\end{tabular}

Within a decade, research methods with secondary data (17 articles) dominated the most in XBRL research, followed by survey ( 3 articles) and case study ( 1 article). Using different samples, these results were in line with Perdana et al. (2015), who found that the most widely used data collection technique in XBRL-themed research was secondary data. Furthermore, based on the theme of research, the the me of Influence of XBRL on Business is widely done in Indonesia, with as many as 16 articles, followed by the theme on XBRL Technical Development, as many as two articles. These results are the same (though directly disproportionate) as the results obtained by Perdana et al. (2015), whose research scope is international, and found that the authors were more interested in researching how XBRL affects businesses. Moreover, there are also two articles related to the theme of XBRL Education. 


\section{Review: Current XBRL Research Streams}

\subsection{Research Theme 1: XBRL's Impact on Business}

Since the last three years (2018-2020), XBRL research in Indonesia has led to many ways XBRL influences and/or benefits the business process. The benefits of the presence of XBRL were felt both internally and externally by parties that use XBRL directly for reporting, including accountants and consultants, as well as by parties that utilize and have the interest in the financial statements of related companies such as data aggregators, analysts, standards boards and regulators, and also software developers (Bonson, 2001). Furthermore, XBRL is the embodiment of the universality of data language, so communication between users and companies, companies and companies to regulators, is interactive without interruption using different system platforms (Zamroni and Aryani, 2018). In the background, to meet the needs of businesses with the utilization of the format below is a detailed explanation of how XBRL influences business processes and activities in Indonesia.

The field of accounting discusses how XBRL affects the financial report system and corporate governance. Organizations or companies can automate the process of preparing financial statements more accurately, clearly, and easily attributable by all stakeholders in the necessary formats (Perdana et al., 2015). This XBRL reporting format enhances financial statement quality, meaning that when the XBRL reporting format is used, it reduces the likelihood of accrual policies from management to improve the quality of financial statements (Prasetyo and Apandi, 2019). For example, in banking organizations, it was found that banks reporting financial statements using XBRL had better quality than those that did not use XBRL (Prasetyo and Apandi, 2019). In general, XBRL can answer the challenges of today's business, i.e., better manage ment, low cost, and fast service (Perdana et al., 2015).

In Indonesia, at the beginning of the implementation of XBRL, evidence was found that XBRL had not had a significant effect yet on improving the quality of the financial information environment (Zamroni and Aryani, 2018). Furthermore, the XBRL adoption also did not affect reducing information asymmetry (Tohang et al., 2020), even it had a positive effect in increasing information asymmetry (Jayani et al., 2020). This 
can occur partly because the taxonomy used is still limited (includes items in financial statements only) (Zamroni and Aryani, 2018) and still in the early stage of adoption (Tohang et al., 2020).

However, in the other study, the adoption of XBRL is proven to reduce the asymmetry of information and corporate governance reflected from the level of transparency of reports that are following the standards proven to be able to reduce the asymmetry of information (see, e.g., Dharmawati and Harahap, 2018). Moreover, there is an increase in value relevance in accounting information (Yovalti and Sumiyana, 2018) and quality of financial reporting (Prasetyo and Apandi, 2019) after applying XBRL. However, in terms of cost of debt and cost of equity, the mixed results were found. Tunjungsari and Wibisono (2019) found that XBRL has no effect on the cost of debt but has a significant effect on the cost of capital (see, e.g., Sibarani and Wibisono, 2019; Lusiana and Tohang, 2020).

Meanwhile, a recent study explained that the application of XBRL could minimize the level of earnings management (Mayapada et al., 2020). XBRL enables improved financial reporting transparency and quality, and in turn, it also increases investor confidence in the capital markets. Investors are found to differentiate between adopters firm and non-adopters firm of XBRL (Junus and Irwanto, 2021), although the adoption of XBRL did not affect earnings value relevance (Muchlis et al., 2019). In terms of information risk, the implementation of XBRL can reduce the risk of information on financial reporting and can lead to improved quality of financial statements (Pamungkas and Kristanto, 2019).

Perdana et al. (2015) found limited research in this field of user interaction with XBRL. The same is happening in Indonesia. If Perdana mentions a subtheme with user perception and decision-making performance, the subtheme in this study is limited to user perception only, both internal and external. For example, investigate how the benefits of XBRL are perceived by internal users (such as preparers) who prepare the reporting on an XBRL basis. Meanwhile, external users who have an interest in financial statements and how their perception of financial statements has been processed using XBRL reporting base are, for example, investors and auditors. XBRL 
data integration and the conversion result in cost and time efficiency. From the user's perspective, the resulting financial statements are more timely, accurate, and transparent. As a result, the analysis and evaluation activities that form the basis in business decision-making can be done more effectively and efficiently (Perdana et al., 2015).

Regarding investor perceptions, there is still limited publication or related literature on how investor perceptions of XBRL-based financial reporting policies related to its effectiveness and efficiency. However, some studies do little to illustrate the overall influence, although not in the case of Indonesia. XBRL format that demands full disclosure can produce adequate information for investors (Jayani et al., 2020). With the presentation of transparent data and can be observed more easily by stakeholders, the decision-making process in companies can be done more quickly and improve the ease of access to financial information for international investors (see, e.g., Junus and Irwanto, 2021). It is suggested that firms that have not delivered their financial statements with XBRL create an XBRL format to serve certainty and accessibility for investors and potential investors (Prasetyo and Apandi, 2019).

One of the benefits of XBRL also provides an advantage for auditors in performing their duties. In particular, XBRL provides the opportunity and ability for auditors to perform continuous audits by accessing the financial data information from databases without depending on traditional financial statements (Rezaee et al., 2002). This way, the auditing process can run efficiently. In the case of Indonesia, there are still two articles that have performed empirical research related to audit and XBRL. Research that discusses topics related to audit delay found that complex accounting reporting makes audit delays longer and audit costs higher (Saputro and Achjari, 2020). However, the variable of delay of this audit depends on the type of industry. The financial industry that tends to adopt XBRL has achieved optimal audit delay. The mandatory use of XBRL by the Indonesia Stock Exchange does not make changes to audit delays.

Meanwhile, the non-financial industry that tends to be slow in adopting XBRL still has room for improvement in terms of audit delays (Saputro and Achjari, 2020). On the other hand, the adoption of XBRL has no significant effect on audit fees (W and 
Sumiyana, 2020). Furthermore, in other research with external auditors as a unit analysis, it was found that of the four factors (namely prior knowledge, communication networks, cognitive abilities, and communication climate), only communication networks had a significant impact on auditors' self-efficacy (Pawestri and Ali, 2019).

\subsection{Research Theme 2: XBRL's Adoption}

Themes related to the adoption of XBRL include XBRL adoption drivers and adopters at both the levels of individual and organizational and the XBRL adopters' characteristics (Perdana et al., 2015). Several models or frameworks can be used to measure technology adoption, both at the individual and organizational levels. For example, innovation Diffusion Theory, Theory Reasoned Action, Expectation Confirmation Theory, Expectation Confirmation Model, Technology Acceptance Model (TAM), Theory of Planned Behavior (TPB) are models used at an individual level. Typically, models or frameworks are used in measuring the adoption of technology, especially in the organizational spheres, namely Technological, Organization, and Environmental (TOE) theory.

XBRL's discussion of its adoption in Indonesia tends to be very limited. This can be observed from the findings of articles that have the theme of exposure. Only two studies conduct empirical research (see, e.g., Muchlis et al., 2019; Prasetia and Wijayana, 2017). In the early stage of XBRL adoption, the firms' leverage, size as well as property, plant, and equipment, and consistency in using the services of Big 4 auditors have a significant effect in differentiating companies that use XBRL and those that do not use XBRL (Prasetia and Wijayana, 2017). In addition to the previous study, it was also found that the firm size and profitability and the role of financial expertise on the board were the determinants in the early adoption of XBRL (Muchlis et al., 2019). Another study (not specifically discuss the XBRL studies) mentioned that the size of the company and leverage have a significant effect on Internal Financial Reporting (IFR), which is the disclosure of financial and non-financial information of the company through the official web system of the company where one of them uses the XBRL format (Maulana and Almilla, 2018). 


\subsection{Research Theme 3: XBRL's Technological Development}

Perdana et al. (2015) explained that the topic discusses how XBRL should be developed technically to facilitate the integration of enterprise applications and business processes. In contrast to the findings, XBRL research in Indonesia that discusses this topic is still limited to the prototype. Wijanarko and Moedjiono (2015) conducted research that discussed building an XBRL-based and web-based reporting system at a bank in Indonesia with the scope of discussing data management and adjusting data with taxonomies regulators and forming XML report results. Users can also develop an XBRL-based reporting system by building information system applications corresponding to taxonomy. Using the method of developing a web-based prototype model information system, users can provide integrated reporting data and support the speed of reporting services to BI (Wijanarko and Moedjiono, 2015). The web-based reporting system software has good quality in terms of functionality, reliability, usability, and efficiency (Wijanarko and Moedjiono, 2015).

$\mathrm{XBRL}$, as an adaptive standard-based system, can improve the use of electronic reporting systems, facilitate the publication of financial reports because of its compatibility, increase efficiency, and increase the ease of access to financial information for stakeholders (Wirabuana and Nugraha, 2014).

\subsection{Research Theme 4: XBRL's Education}

XBRL has been present since 2000, but the distribution of acceptance and use in various countries of this technology tends to be long. In various theories regarding technological readiness such as TAM, TOE, Technology Readiness, and so on, one has indicators related to knowledge and skills, or broadly that is education. According to Perdana et al. (2015), there are several ways to teach XBRL, including introducing mechanisms, the practice of creating XML documents, interacting with software, expanding the XBRL taxonomy, analyzing the stages of creating XBRL instance documents, etc. In Indonesia, we found limited literature discussing how XBRL materials can be included in the accounting curriculum (see, e.g., Wulandari and Ali, 
2019) and a study related to the awareness and understanding of educators or accountants toward XBRL (Pujisari and Biyanto, 2019).

XBRL materials and their preparations are two elements that must be enhanced to convey better XBRL knowledge (Perdana et al., 2015). However, based on the survey distributed to the accounting lecturers in Indonesia, it is found that XBRL material has not been given well in the accounting courses (Ali, 2020). The obstacle in realizing the XBRL curriculum, especially at the undergraduate level, is that academics who teach accounting in Indonesia do not know the benefits of incorporating XBRL topics into their curriculum, so most of them have not integrated XBRL topics (Wulandari and Ali, 2019). This is also supported by Pujisari and Biyanto's (2019) study, which confirms that the knowledge of accounting lecturers toward XBRL is very lacking, and their understanding is low. However, academics or lecturers have a high interest in studying this topic (Pujisari and Biyanto, 2019).

In some universities, XBRL has been introduced in the accounting learning process. Wulandari and Ali (2019) state that most academics who teach accounting systems already included XBRL topics in classes. In addition to the need for massive socialization about XBRL, a gradual system is needed in applying XBRL education to the accounting curriculum. There is no denying that the topic of XBRL is important to be included in the accounting curriculum as a knowledge supply for graduates demanded by technological developments (Pujisari and Biyanto, 2019).

\section{A framework of XBRL Research and Future Potential Research Areas in Indonesia}

The development of research discussing XBRL in Indonesia in recent years has increased (see Figure 2). In the last ten years, peer-reviewed scientific articles using secondary data (archival data) have dominated XBRL research in Indonesia. However, in line with Perdana's (2015) research, XBRL's research in Indonesia is still dominated by quantitative methods such as secondary data (archival data), followed by surveys using questionnaire instruments. Quantitative research with these questionnaire instruments can produce measurable explanations. Researchers can then use this quantitative study and/or secondary data collaboration with primary data. 
Referring to a previous study by Perdana et al. (2015), this article also proposes four research topics related to XBRL in Indonesia. The first research topic is the influence of XBRL on business. The majority of research has investigated how XBRL affects business both from improving the quality of financial statements in terms of financial accounting (e.g., timelines, information quality, information asymmetry, information risk), market reaction, auditing (e.g., audit delay and audit fees), and earnings management. Nevertheless, there are still many gaps that need to be investigated in looking at how XBRL is developing in Indonesia, especially its influence on business activities. Extensions of previous studies can be done due to some mixed results found for a particular topic: information asymmetry, information risk, information quality, market efficiency, earnings management, cost of debt, or other financial reports effectivity and efficiency. In addition, the future researcher can research with a longer year span by using a comparative study from before and after adopting XBRL on ISE-listed companies, with any industries such as finance and nonfinance.

Previous studies still focused on using secondary data (archival data) only without collecting primary data such as interviews or surveys with questionnaires to XBRL users, especially the investors and the auditors. There is a need to study about how investors' perception of XBRL financial reporting. Input from them is needed to improve the taxonomy of the XBRL format in the future. Besides, adding other variables (as moderator and/or mediator) according to each topic is also necessary to expand and get more nuanced research results, thus add stakeholders' insights related to the influence of XBRL. Exploration of auditing aspects is also a potential topic that can be further studied, such as by using corporate governance variables, audit opinions, liquidity risk ranges, or continuing delay audit research but by looking at delays in submitting audited financial statements to improve the audit process and support ongoing audits (Saputro and Achjari, 2020).

In addition to observing the aspects of financial statements, it is also necessary to investigate how subjective the perceptions of XBRL users are internally, such as in companies that use XBRL-based financial statements and externally, such as on 
investors, auditors, and other related stakeholders. Furthermore, empirical research related to user perception from different industries related to XBRL can also be conducted. For example, further study needs to investigate how interactive data allows users, especially investors, to reach better decisions (Perdana et al., 2015). Other things, for example, the researcher can use survey research on external users before and after the XBRL to examine the influence of stakeholders' beliefs and attractiveness (see, e.g., Zamroni and Aryani, 2018). Moreover, empirical studies investigating the effects of XBRL on good corporate governance, decisions to outsource or maintain in-house XBRL adoption, and XBRL adoption in the public sector are still limited (Perdana et al., 2015). Finally, research from the XBRL software provider side also needs to be performed, such as regarding the potential adoption of XBRL for non-listed companies.

The second topic is the adoption of XBRL. Research related to the adoption of $\mathrm{XBRL}$ in Indonesia is also still limited. However, studies related to XBRL adoption readiness and acceptance using common theoretical frameworks both at the individual and organizational level in Indonesia can be performed. Researchers can then evaluate the adoption of XBRL for internal and external use. Thus, the research results can be useful to be an overview of the possibility of future improvement and adoption in nonlisted firms and/or other institutions in Indonesia. In addition to examining the adoption of XBRL described earlier, the potential for future research can also trace the adoption of XBRL to non-listed companies and voluntarily use using case studies. The investigation into this issue is an exciting potential for further study.

Furthermore, in the third topic that discusses the technical developments of XBRL, there is a need to learn about taxonomic design, taxonomic interoperability, and adoption of these developments (Alles and Debreceny, 2012). With the benefits of XBRL to integrate and present data, taxonomic design is really important to explore the research area, especially in Indonesia. This need is increasing towards XBRL financial reporting, which will involve a disclosure section. The implementation of XBRL, which is still done separately by several agencies in Indonesia, investigating the potential of adopting single taxonomy in a country (commonly known as XBRL national jurisdiction) may be one of the things that can be considered. Furthermore, the 
development of XBRL taxonomy for integrated reporting with coordination between authorities can support the maximum utilization of XBRL. For example, several national authorities might require their certain reporting taxonomy to report the local accounting based on their regulations. In addition, many different organizations may require taxonomic extensions to meet their own specific business reporting needs (XBRL, 2021). Table 6 summarizes the themes of research found that have the potential to be performed in future research.

Further study can also investigate the readiness and the potential integration of XBRL-Global Ledger taxonomy and XBRL-Financial Reporting taxonomy with the entire enterprise resource planning process (ERP) (Perdana et al., 2015). Consideration regarding the addition of extension taxonomy or taxonomic integration is an important point. In practice, related to the use of XBRL taxonomy, especially the aspects of its complexity and compatibility, a researcher can also trace and verify it. Those both aspects can become an evaluation of knowledge for potential users.

Finally, there is also the topic of XBRL education. Educational indicators are some of the factors in the successful adoption of XBRL. As a relatively new technology in Indonesia, knowledge, and awareness of this technology play an important role. In the company's case, it can be studied the role of training or educational facilities related to XBRL (if any) to enhance internal users' capability in preparing timely and high-quality XBRL financial reporting. Consciousness becomes inseparable in education. Therefore, research related to strategies in raising awareness of XBRL education for users both internally (such as in-house training) and externally can drive the effectiveness of XBRL utilization.

Furthermore, education about XBRL, especially at the higher education level, needs to be incorporated into the curriculum. Based on previous reviews, it appears that XBRL education in the curriculum in Indonesia is still limited. However, some universities have included the XBRL curriculum in information systems and/or some accounting courses. Thus, studies related to the effectiveness of XBRL teaching materials to improve student understanding can also be conducted. 
Table 6.

Future Research Areas

\begin{tabular}{|c|c|c|}
\hline Topic & Future Research Areas & $\begin{array}{l}\text { Potential Research } \\
\text { Methods to Address } \\
\text { the Research Areas }\end{array}$ \\
\hline \multirow[t]{7}{*}{$\begin{array}{l}\text { XBRL's Impact } \\
\text { on Business }\end{array}$} & $\begin{array}{l}\text { To investigate the effect of XBRL-based financial } \\
\text { statements on the company's financial } \\
\text { information. }\end{array}$ & $\begin{array}{l}\text { Secondary data, } \\
\text { Survey, } \\
\text { Interview }\end{array}$ \\
\hline & $\begin{array}{l}\text { To investigate the effect of the use of XBRL- } \\
\text { based financial statements on auditing. }\end{array}$ & $\begin{array}{l}\text { Secondary data, } \\
\text { Survey, } \\
\text { Interview }\end{array}$ \\
\hline & $\begin{array}{l}\text { To investigate the subjective perception of XBRL } \\
\text { users both internally and externally, } \\
\text { including investors and potential investors. }\end{array}$ & Survey, Interview \\
\hline & $\begin{array}{l}\text { To investigate the views and benefits perceived } \\
\text { by the investors }\end{array}$ & $\begin{array}{l}\text { Secondary data, } \\
\text { Survey, } \\
\text { Interview }\end{array}$ \\
\hline & $\begin{array}{l}\text { To investigate the benefits of outsourcing XBRL } \\
\text { versus doing in-house XBRL for efficiency } \\
\text { and effectiveness of financial reporting } \\
\text { (Perdana et al., 2015) }\end{array}$ & Survey, Interview \\
\hline & To investigate the potential implementation of & Study, \\
\hline & $\begin{array}{l}\text { XBRL in the public sector (Perdana et al., } \\
\text { 2015) }\end{array}$ & Interview \\
\hline \multirow{5}{*}{$\begin{array}{l}\text { XBRL's } \\
\text { Adoption }\end{array}$} & XBRL adoption readiness using common & Case Study, Survey, \\
\hline & $\begin{array}{l}\text { theoretical frameworks at the individual and } \\
\text { organizational level }\end{array}$ & Into \\
\hline & $\begin{array}{l}\text { Evaluating the adoption of XBRL for internal and } \\
\text { external use }\end{array}$ & $\begin{array}{l}\text { Case Study, Survey, } \\
\text { Interview }\end{array}$ \\
\hline & $\begin{array}{l}\text { Investigating the effect of mandatory XBRL } \\
\text { adoption }\end{array}$ & $\begin{array}{l}\text { Case Study, Survey, } \\
\text { Interview }\end{array}$ \\
\hline & $\begin{array}{l}\text { Exploring XBRL adoption in non-listed } \\
\text { companies and its voluntarily use }\end{array}$ & $\begin{array}{l}\text { Case Study, Survey, } \\
\text { Interview } \\
\end{array}$ \\
\hline \multirow{8}{*}{$\begin{array}{l}\text { XBRL's } \\
\text { Technological } \\
\text { Development }\end{array}$} & Taxonomic & Science \\
\hline & $\begin{array}{l}\text { stakeholders/government/governance } \\
\text { reporting in the development of XBRL }\end{array}$ & Research, Case Study \\
\hline & $\begin{array}{l}\text { Investigating one-size-fits-all company } \\
\text { taxonomy vs. industry-specific taxonomy }\end{array}$ & $\begin{array}{l}\text { Case Study, Survey, } \\
\text { Interview }\end{array}$ \\
\hline & $\begin{array}{l}\text { Investigating the influence of taxonomic XBRL } \\
\text { extensions }\end{array}$ & $\begin{array}{l}\text { Case Study, Survey, } \\
\text { Interview }\end{array}$ \\
\hline & $\begin{array}{l}\text { Analysis of the adoption of single taxonomy in } \\
\text { the country/XBRL national jurisdiction }\end{array}$ & $\begin{array}{l}\text { Case Study, Survey, } \\
\text { Interview }\end{array}$ \\
\hline & $\begin{array}{c}\text { Investigating XBRL validators in } \mathrm{XBRL} \\
\text { development }\end{array}$ & $\begin{array}{l}\text { Case Study, Survey, } \\
\text { Interview }\end{array}$ \\
\hline & Analysis of XBRL assurance & Design Science \\
\hline & & Research, Case Study \\
\hline
\end{tabular}




\begin{tabular}{lcl}
\hline Topic & Future Research Areas & $\begin{array}{l}\text { Potential Research } \\
\text { Methods to Address } \\
\text { the Research Areas }\end{array}$ \\
\hline XBRL's & $\begin{array}{l}\text { Investigating XBRL-related education and } \\
\text { awareness strategies for users }\end{array}$ & $\begin{array}{l}\text { Case } \\
\text { Interview } \\
\text { Investigating the effectiveness of teaching } \\
\text { XBRL materials to improve student }\end{array}$ \\
& Survey, Interview \\
& understanding &
\end{tabular}

Source: Perdana et al. (2015), re-processed by the authors

\section{Conclusion, Implication, and Limitation}

\subsection{Conclusion}

The research of XBRL implementation has emerged and increased substantially worldwide, both in developed and developing countries. One of the reasons is that XBRL has a significant and important role in financial reporting nowadays. Meanwhile, this paper concerns a literature review about the current state of XBRL research in the Indonesian setting. A review of articles on the last decade will provide us with up-todate insights for XBRL research in Indonesia.

This study has reviewed the XBRL research in Indonesia over the past decade and provided suggestions for future research. In achieving the research objective, this study conducted an integrative review by identifying articles related to XBRL research in Indonesia in the form of reputable and scientific journals/scientific papers published and the thesis from the top ten universities in Indonesia. We classified the studies into four themes, i.e., XBRL's Impact on Business, XBRL's Adoption, XBRL's Technological Development, and XBRL's Education. Based on the review results, $\mathrm{XBRL}$ research in Indonesia is still limited in using empirical research with quantitative methods, especially by using secondary data (archival data). Therefore, we suggest the potential research areas execute more advanced research to acquire more comprehensive results.

Reflecting on the literature study conducted by Perdana et al. (2015), it can also be concluded that the development of academic research on XBRL in Indonesia is at least in line with the development of academic research at the international level. In other 
words, XBRL studies in Indonesia confirm academic research at the international level, although the quality and variety of some studies are not as good as international studies. Finally, this study can be a reference source of knowledge that can inspire other developing countries that plan to adopt or have adopted the XBRL format.

\subsection{Implication and Limitation}

This study provides a potential future research framework that can be used to reference future Indonesian and international researchers in exploring empirical findings related to the XBRL format.

The limitation of this research can be explained as follows. First, due to limited research related to XBRL with the context of Indonesia published in reputable international journals (indexed in Scopus) and national journals (indexed in Sinta), the criteria are expanded. Thus, it also involves a thesis from the top ten universities in Indonesia. However, these theses have not passed an external peer review and conducted revisions needed. Then, there is the potential for several papers regarding XBRL research in Indonesia to be published before May 2021, but the editorial team is late in publishing it on the journal website; hence it is beyond the authors' control. In addition, there are few sources of scientific articles that were unsuccessful for in-depth review due to limited access. 


\section{References}

Ali, S. (2020). Revolusi Industri 4.0 dan Dampaknya terhadap Pendidikan Akuntansi di Indonesia. Yogyakarta: Badan Penerbit Fakultas Ekonomi.

Alles, M., \& Debreceny, R. (2012). The evolution and future of XBRL research. International Journal of Accounting Information Systems, 13(2), 83-90. https://doi.org/10.1016/j.accinf.2012.03.006

Arnold, V., Bedard, J. C., Phillips, J. R., \& Sutton, S. G. (2012). The impact of tagging qualitative financial information on investor decision making: Implications for XBRL. International Journal of Accounting Information Systems, 13(1), 2-20. https://doi.org/10.1016/j.accinf.2011.12.002

Baldwin, A. A., Brown, C. E., \& Trinkle, B. S. (2006). XBRL: An Impacts Framework and Research Challenge. Journal of Emerging Technologies in Accounting, 3(1), 97-116. https://doi.org/https://doi.org/10.2308/jeta.2006.3.1.97

Bergman, M. M. (2007). Media Review: Foundations of Multimethod Research: Synthesizing Styles (2nd ed). Journal of Mixed Methods Research, 1(1), 101-103. https://doi.org/10.1177/2345678906291429

Bonson. (2001). The Role of XBRL in Europe. The International Journal of Digital Accounting Research, 1(2), 101-110. https://doi.org/10.4192/1577-8517-v1_5

Bonsón, E., Cortijo, V., \& Escobar, T. (2009). Towards the global adoption of XBRL using International Financial Reporting Standards (IFRS). International Journal of Accounting Information $\quad$ Systems, $\quad$ 46-60. https://doi.org/10.1016/j.accinf.2008.10.002

Debreceny, R., \& Farewell, S. (2010). XBRL in the accounting curriculum. Issues in Accounting Education, 25(3), 379-403. https://doi.org/10.2308/iace.2010.25.3.379

Dharmawati, R., \& Harahap, S. N. (2018). Pengaruh pengadopsian XBRL terhadap asimetri informasi dengan pemoderasi corporate governance. (Undergraduate Thesis, Universitas Indonesia).

Doolin, B., \& Troshani, I. (2004). XBRL: A RESEARCH NOTE. QRAM, 1(2), 93-104.

Hevner, A. R., March, S. T., Park, J., \& Ram, S. (2004). Two Paradigms on Research Essay Design Science in Information Systems Research. MIS Quarterly, 28(1), 75-79.

Hoitash, R., Hoitash, U., \& Morris, L. (2020). eXtensible Business Reporting Language: A Review and Direction for Future Research. XBRL Research.

Janvrin, D. J., \& No, W. G. (2012). XBRL implementation: A field investigation to identify research opportunities. Journal of Information Systems, 26(1), 169-197. https://doi.org/10.2308/isys-10252 
Jayani, E., Winata, J. A., \& Harahap, K. (2020). The XBRL Technology and Market Efficiency in Banking Companies Listed on the Indonesia Stock Exchange (IDX). 4(1), 20122017.

Junus, O., \& Irwanto, A. (2021). Stock Reaction to the Implementation of Extensible Business Reporting Language. Journal of Asian Finance, Economics, and Business, 8(1), 675685. https://doi.org/10.13106/jafeb.2021.vol8.no1.675

La Torre, M., Valentinetti, D., Dumay, J., \& Rea, M. A. (2018). Improving corporate disclosure through XBRL: An evidence-based taxonomy structure for integrated reporting. Journal of Intellectual Capital, 19(2), 338-366. https://doi.org/10.1108/JIC-03-20160030

Lusiana, S., \& Tohang, V. (2020). Digitalization of Financial Reporting Through XBRL and the Cost of Equity in Indonesian Listed Firms. (Undergraduate Thesis, Bina Nusantara University).

Mahardika, S. A., \& Harahap, S. N. (2018). Analisis Pengaruh Adopsi Xbrl Terhadap Asimetri Informasi Dengan Corporate Governance Sebagai Pemoderasi. Jurnal Akuntansi Dan Keuangan Indonesia, 15(2), 217-236. Retrieved from http://jaki.ui.ac.id/index.php/home/article/view/1637/pdf_12

Maulana, I. R., \& Almilla, L. S. (2018). Factors Affecting the Internet Financial Reporting(IFR) in Banking Sector Companies Listed on the Indonesia Stock Exchange (IDX). The Indonesian Accounting Review, 8(2), 219. https://doi.org/10.14414/tiar.v8i2.1539

Mayapada, A. G., Afdhal, M., \& Syafitri, R. (2020). Earnings Management in the Pre and Post eXtensible Business Reporting Language Period in Indonesia. The Indonesian Journal of Accounting Research, 23(01), 29-48. https://doi.org/10.33312/ijar.459

Mindzak, J. (2009). Literature Review of Internet Financial Reporting and XBRL.

Muchlis, F., Primadyan, M., R. Shauki, E., \& Diyanty, V. (2019). xamining XBRL Early Adopters: A Study of Determinants and Value Relevance. 89(Apbec 2018), 267-274. https://doi.org/10.2991/apbec-18.2019.35

Neuman, W. L. (2014). Social Research Methods: Qualitative and Quantitative Approaches. In Pearson Education Limited (Seventh Ed). Pearson Education Limited.

Palvia, P., Pinjani, P., \& Sibley, E. H. (2007). A profile of information systems research published in Information \& Management. Information and Management, 44(1), 1-11. https://doi.org/10.1016/j.im.2006.10.002

Pamungkas, Y. A., \& Kristanto, A. B. (2019). Dampak Implementasi XBRL terhadap Risiko Informasi. Kompartemen: Jurnal Ilmiah Akuntansi, XVII(1), 48-60. Retrieved from http://jurnalnasional.ump.ac.id/index.php/kompartemen/

Pawestri, A. B., \& Ali, S. (2019). Analisis Faktor-Faktor yang Memengaruhi Self-Efficacy Auditor Eksternal di Indonesia terhadap XBRL. (Undergraduate Thesis, Universitas 
Gadjah Mada).

Perdana, A., Robb, A., \& Rohde, F. (2015). An integrative review and synthesis of XBRL research in academic journals. Journal of Information Systems, 29(1), 115-153. https://doi.org/10.2308/isys-50884

Pinsker, R., \& Wheeler, P. (2009). Non-professional investors perceive the efficiency and effectiveness of XBRL-enabled financial statement analysis and firms providing XBRL-formatted information. International Journal of Disclosure and Governance, 6(3), 241-261. https://doi.org/10.1057/jdg.2009.6

Prasetia, D., \& Wijayana, S. (2017). Perbedaan Karakteristik Perusahaan Sebelum Diwajibkannya Laporan Keuangan Berbasis XBRL di Indonesia di Tahun 2015: Perbandingan Antara Perusahaan yang Menggunakan XBRL dan Tidak Menggunakan XBRL. (Master Thesis, Universitas Gadjah Mada). Retrieved from http://etd.repository.ugm.ac.id/home/detail_pencarian/131049

Prasetyo, H., \& Apandi, N. N. (2019). Does Xbrl Improve the Quality of Financial Statements in the Banking Industry? The International Journal of Business Review (The Jobs Review), 2(2), 137-158. https://doi.org/10.17509/tjr.v2i2.20499

Pujisari, Y., \& Biyanto, F. (2019). Kesadaran (Awareness) dan Pemahaman (Understanding) Akuntan Pendidik terhadap XBRL. INVENTORY: Jurnal Akuntansi, 3(1), 33-46.

Rezaee, Z., Sharbatoghlie, A., Elam, R., \& McMickle, P. L. (2002). Continuous auditing: Building automated auditing capability. Auditing, 21(1), 147-163. https://doi.org/10.2308/aud.2002.21.1.147

Roohani, S., Furusho, Y., \& Koizumi, M. (2009). XBRL: Improving transparency and monitoring functions of corporate governance. International Journal of Disclosure and Governance, 6(4), 355-369. https://doi.org/10.1057/jdg.2009.17

Saputro \& Achjari. (2020). Pengaruh Penggunaan XBRL Terhadap Audit Delay pada Industri Keuangan dan Non-Keuangan di Indonesia. 10(September), 153-169. https://doi.org/10.34010/jati.v10i2

Sibarani, S. H. N., \& Wibisono, G. (2019). Pengaruh adopsi xbrl dan asimetri informasi terhadap. (Undergraduate Thesis, Universitas Gadjah Mada).

Srivastava, R. P., \& Liu, Q. (2012). Special issue of JIS on XBRL. Journal of Information Systems, 26(1), 97-101. https://doi.org/10.2308/isys-10255

Tohang, V., Limijaya, A., \& Chitrahadi, M. (2020). An analysis of the impact of XBRL filings towards information asymmetry in Indonesia. Proceedings of 2020 International Conference on Information Management and Technology, ICIMTech 2020, (August), 330-335. https://doi.org/10.1109/ICIMTech50083.2020.9211114 
Troshani, I., Parker, L. D., \& Lymer, A. (2015). Institutionalising XBRL for financial reporting: Resorting to regulation. Accounting and Business Research, 45(2), 196-228. https://doi.org/10.1080/00014788.2014.980772

Tunjungsari, A. L., \& Wibisono, G. (2019). Pengaruh Adopsi XBRL terhadap Cost of Debt pada Perusahaan yang Terdaftar di Indeks Kompas 100 BEI Periode 2012-2017. (Undergraduate Thesis, Universitas Gadjah Mada).

W, H. F., \& Sumiyana. (2020). Pengaruh Adopsi XBRL Terhadap Audit Laporan Keuangan pada Perusahaan yang Terdaftar di Bursa Efek Indonesia Periode 2012-2017. (Undergraduate Thesis, Universitas Gadjah Mada).

Wang, T., Wen, C. Y., \& Seng, J. L. (2014). The association between the mandatory adoption of XBRL and the performance of listed state-owned enterprises and non-state-owned enterprises in China. Information and Management, 51(3), 336-346. https://doi.org/10.1016/j.im.2014.02.006

Wijanarko, H., \& Moedjiono. (2015). 128-262-1-PB.pdf. Jurnal Telematika MKOM.

Wirabuana, C., \& Nugraha, I. G. D. (2014). Analisa Performance Teknologi XBRL untuk Laporan Keuangan pada Industri Keuangan. (Undergraduate Thesis, Universitas Indonesia).

Wulandari, S. S., \& Ali, S. (2019). Incorporating XBRL topics into the accounting curriculum: empirical evidence from Indonesia. Accounting Education, 28(6), 597-620. https://doi.org/10.1080/09639284.2019.1679205

XBRL. (2021). Taxonomies. Retrieved May 26, 2021, from XBRL International website: https://www.xbrl.org/the-standard/what/taxonomies/

Yovalti, A. O., \& Sumi yana. (2018). Relevansi Nilai Informasi Akuntansi Sebelum dan Sesudah Penerapan XBRL di Bursa Efek Indonesia. (Undergraduate Thesis, Universitas Gadjah Mada).

Zamroni, M., \& Aryani, Y. A. (2018). Initial Effects of Mandatory XBRL Adoption across the Indonesia Stock Exchange's Financial Information Environment. Jurnal Keuangan Dan Perbankan, 22(2), 181-197. https://doi.org/10.26905/jkdp.v22i2.2092

Zhang, Y., Guan, Y., \& Kim, J. B. (2019). XBRL adoption and expected crash risk. Journal of Accounting and Public Policy, 38(1), 31-52. https://doi.org/10.1016/j.jaccpubpol.2019.01.003 


\section{Appendix}

Article Used in the Literature Review

\begin{tabular}{|c|c|c|c|c|c|}
\hline No. & The me and Title & Method & $\begin{array}{l}\text { Author(s), } \\
\text { year }\end{array}$ & Type & Publisher \\
\hline \multicolumn{6}{|c|}{$\begin{array}{l}\text { XBRL's impact on } \\
\text { business }\end{array}$} \\
\hline 1 & $\begin{array}{l}\text { Stock Reaction to the } \\
\text { Implementation of } \\
\text { Extensible Business } \\
\text { Reporting Language }\end{array}$ & $\begin{array}{l}\text { Secondary } \\
\text { Data }\end{array}$ & $\begin{array}{l}\text { Junus and } \\
\text { Irwanto } \\
(2021)\end{array}$ & $\begin{array}{l}\text { International } \\
\text { Journal }\end{array}$ & $\begin{array}{l}\text { Journal of } \\
\text { Asian Finance, } \\
\text { Economics, } \\
\text { and Business }\end{array}$ \\
\hline 2 & $\begin{array}{l}\text { Does XBRL improve } \\
\text { the quality of financial } \\
\text { statements in the } \\
\text { banking industry? }\end{array}$ & $\begin{array}{l}\text { Secondary } \\
\text { Data }\end{array}$ & $\begin{array}{l}\text { Prasetyo } \\
\text { and Apandi } \\
(2019)\end{array}$ & $\begin{array}{l}\text { International } \\
\text { Journal }\end{array}$ & $\begin{array}{l}\text { The } \\
\text { International } \\
\text { Journal of } \\
\text { Business } \\
\text { Review }\end{array}$ \\
\hline 3 & $\begin{array}{l}\text { An Analysis of the } \\
\text { Impact of XBRL Filings } \\
\text { Towards Information } \\
\text { Asymmetry in } \\
\text { Indonesia }\end{array}$ & $\begin{array}{l}\text { Secondary } \\
\text { Data }\end{array}$ & $\begin{array}{l}\text { Tohang et } \\
\text { al. }(2020)\end{array}$ & $\begin{array}{l}\text { International } \\
\text { Proceedings }\end{array}$ & $\begin{array}{l}\text { International } \\
\text { Conference on } \\
\text { Information } \\
\text { Management } \\
\text { and } \\
\text { Technology }\end{array}$ \\
\hline 4 & $\begin{array}{l}\text { Pengaruh Penggunaan } \\
\text { XBRL Sesuai Instruksi } \\
\text { Bursa Efek Indonesia, } \\
\text { Ukuran Perusahaan, } \\
\text { dan Jenis Industri } \\
\text { Terhadap Audit Delay }\end{array}$ & $\begin{array}{l}\text { Secondary } \\
\text { Data }\end{array}$ & $\begin{array}{l}\text { Saputro and } \\
\text { Achajri } \\
(2020)\end{array}$ & $\begin{array}{l}\text { National } \\
\text { Journal }\end{array}$ & $\begin{array}{l}\text { Jurnal } \\
\text { Teknologi dan } \\
\text { Informasi }\end{array}$ \\
\hline 5 & $\begin{array}{l}\text { The XBRL Technology } \\
\text { and Market Efficiency } \\
\text { in Banking Companies } \\
\text { Listed on the Indonesia } \\
\text { Stock Exchange (IDX) }\end{array}$ & $\begin{array}{l}\text { Secondary } \\
\text { Data }\end{array}$ & $\begin{array}{l}\text { Jayani et al. } \\
(2020)\end{array}$ & $\begin{array}{l}\text { National } \\
\text { Journal }\end{array}$ & $\begin{array}{l}\text { Journal of } \\
\text { Community } \\
\text { Service and } \\
\text { Research }\end{array}$ \\
\hline 6 & $\begin{array}{l}\text { Earnings Management } \\
\text { in the Pre and Post } \\
\text { eXtensible Business } \\
\text { Reporting Language } \\
\text { Period in Indonesia }\end{array}$ & $\begin{array}{l}\text { Secondary } \\
\text { Data }\end{array}$ & $\begin{array}{l}\text { Mayapada } \\
\text { et al. }(2020)\end{array}$ & $\begin{array}{l}\text { National } \\
\text { Journal }\end{array}$ & $\begin{array}{l}\text { The } \\
\text { Indonesian } \\
\text { Journal of } \\
\text { Accounting } \\
\text { Research }\end{array}$ \\
\hline 7 & $\begin{array}{l}\text { Initial Effects of } \\
\text { Mandatory XBRL } \\
\text { Adoption } \\
\text { Across The Indonesia } \\
\text { Stock Exchange's } \\
\text { Financial Information } \\
\text { Environment }\end{array}$ & $\begin{array}{l}\text { Secondary } \\
\text { Data }\end{array}$ & $\begin{array}{l}\text { Zamroni } \\
\text { and Aryani } \\
(2018)\end{array}$ & $\begin{array}{l}\text { National } \\
\text { Journal }\end{array}$ & $\begin{array}{l}\text { Jurnal } \\
\text { Keuangan dan } \\
\text { Perbankan }\end{array}$ \\
\hline
\end{tabular}




\begin{tabular}{|c|c|c|c|c|c|}
\hline No. & The me and Title & Method & $\begin{array}{l}\text { Author(s), } \\
\text { year }\end{array}$ & Type & Publisher \\
\hline 8 & $\begin{array}{l}\text { Dampak Implementasi } \\
\text { XBRL terhadap Risiko } \\
\text { Informasi }\end{array}$ & $\begin{array}{l}\text { Secondary } \\
\text { Data }\end{array}$ & $\begin{array}{l}\text { Pamungkas } \\
\text { dan } \\
\text { Kristanto } \\
\text { (2019) }\end{array}$ & $\begin{array}{l}\text { National } \\
\text { Journal }\end{array}$ & $\begin{array}{l}\text { Kompartemen: } \\
\text { Jurnal Ilmiah } \\
\text { Akuntansi }\end{array}$ \\
\hline 9 & $\begin{array}{l}\text { Relevansi Nilai } \\
\text { Informasi Akuntansi } \\
\text { Sebelum dan Sesudah } \\
\text { Penerapan XBRL pada } \\
\text { Bursa Efek Indonesia }\end{array}$ & $\begin{array}{l}\text { Secondary } \\
\text { Data }\end{array}$ & $\begin{array}{l}\text { Yovalti and } \\
\text { Sumiyana } \\
(2018)\end{array}$ & Thesis & $F E B U G M$ \\
\hline 10 & $\begin{array}{l}\text { Pengaruh Adopsi XBRL } \\
\text { terhadap Cost of Debt } \\
\text { pada Perusahaan yang } \\
\text { Terdaftar di Indeks } \\
\text { Kompas } 100 \text { BEI } \\
\text { Periode 2012-2017 }\end{array}$ & $\begin{array}{l}\text { Secondary } \\
\text { Data }\end{array}$ & $\begin{array}{l}\text { Tunjungsari } \\
\text { and } \\
\text { Wibisono } \\
(2019)\end{array}$ & Thesis & FEB UGM \\
\hline 11 & $\begin{array}{l}\text { Pengaruh Adopsi XBRL } \\
\text { Terhadap Audit } \\
\text { Laporan Keuangan } \\
\text { pada Perusahaan yang } \\
\text { Terdaftar di Bursa Efek } \\
\text { Indonesia Periode } \\
2012-2017\end{array}$ & $\begin{array}{l}\text { Secondary } \\
\text { Data }\end{array}$ & $\begin{array}{l}\text { W and } \\
\text { Sumi yana } \\
(2020)\end{array}$ & Thesis & FEB UGM \\
\hline 12 & $\begin{array}{l}\text { Pengaruh Adopsi XBRL } \\
\text { dan Asimetri Informasi } \\
\text { terhadap Cost of Equity } \\
\text { Capital Pada } \\
\text { Perusahaan yang } \\
\text { Terdaftar di Indeks } \\
\text { Kompas } 100 \text { BEI } \\
\text { Periode 2012-2017 }\end{array}$ & $\begin{array}{l}\text { Secondary } \\
\text { Data }\end{array}$ & $\begin{array}{l}\text { Sibarani } \\
\text { and } \\
\text { Wibisono } \\
(2019)\end{array}$ & Thesis & $F E B U G M$ \\
\hline 13 & $\begin{array}{l}\text { Analisis Faktor-Faktor } \\
\text { yang Memengaruhi } \\
\text { Self-Efficacy Auditor } \\
\text { Eksternal di Indonesia } \\
\text { terhadap XBRL }\end{array}$ & Survey & $\begin{array}{l}\text { Pawestri } \\
\text { and Ali } \\
(2019)\end{array}$ & Thesis & FEB UGM \\
\hline 14 & $\begin{array}{l}\text { Pengaruh pengadopsian } \\
\text { XBRL terhadap asimetri } \\
\text { informasi dengan } \\
\text { pemoderasi corporate } \\
\text { governance }\end{array}$ & $\begin{array}{l}\text { Secondary } \\
\text { Data }\end{array}$ & $\begin{array}{l}\text { Dharmawati } \\
\text { and } \\
\text { Harahap } \\
\text { (2018) }\end{array}$ & Thesis & $F E B U I$ \\
\hline 15 & $\begin{array}{l}\text { Digitalization of } \\
\text { Financial Reporting } \\
\text { Through XBRL and the } \\
\text { Cost of Equity in } \\
\text { Indonesian Listed Firms }\end{array}$ & $\begin{array}{l}\text { Secondary } \\
\text { Data }\end{array}$ & $\begin{array}{l}\text { Lusiana and } \\
\text { Tohang } \\
(2020)\end{array}$ & Thesis & Binus \\
\hline
\end{tabular}




\begin{tabular}{clllll}
\hline No. & Theme and Title & Method & $\begin{array}{l}\text { Author(s), } \\
\text { year }\end{array}$ & Type & Publisher \\
\hline 16 & $\begin{array}{l}\text { Analisa Performance } \\
\text { Teknologi XBRL untuk }\end{array}$ & $\begin{array}{l}\text { Secondary } \\
\text { Laporan Keuangan }\end{array}$ & $\begin{array}{l}\text { Wirabuana } \\
\text { and }\end{array}$ & Thesis & FT UI \\
& & $\begin{array}{l}\text { Nugraha } \\
\text { pada Industri Keuangan }\end{array}$ & & & \\
\end{tabular}

\section{XBRL's adoption}

17 Examining XBRL Early Adopters: A Study of

Secondary

Muchlis et International al. (2018)

Proceedings

Determinants and Value

Relevance

18 Perbedaan

Karakteristik

Perusahaan Sebelum

Diwajibkannya Laporan

Keuangan Extensible

Business Reporting

Language (XBRL) di

Indonesia Tahun 2015:

Perbandingan antara

Perusahaan yang

Menggunakan XBRL

dan Tidak

Menggunakan XBRL

\section{XBRL's technical}

development

19 Prototipe Sistem

Pelaporan Bank

Indonesia Berbasis

XBRL: Studi Kasus PT

Bank Tabungan Negara

\section{XBRL education}

20 Incorporating XBRL

topics into the

Survey

Secondary

Data

Data

al. $(2018)$

Proceeding

1st Asia

Pacific

Business and

Economics

Conference

Prasetia and Thesis

Wijayana

(2017)

Case Study
Wijanarko
and
Moedjiono
(2015)

National

Journal

\section{FEB UGM}

Wulandari

International

Accounting

and Ali

Journal

Education

accounting curriculum:

empirical evidence from

Indonesia

21 Kesadaran (Awareness)

dan Pemahaman

(Understanding)

Akuntan Pendidik

(2019)

Pujisari and

National

Inventory:

Biyanto

Journal

Jurnal

(2019)

Akuntansi

terhadap XBRL 
Arfah Habib Saragih et Al 